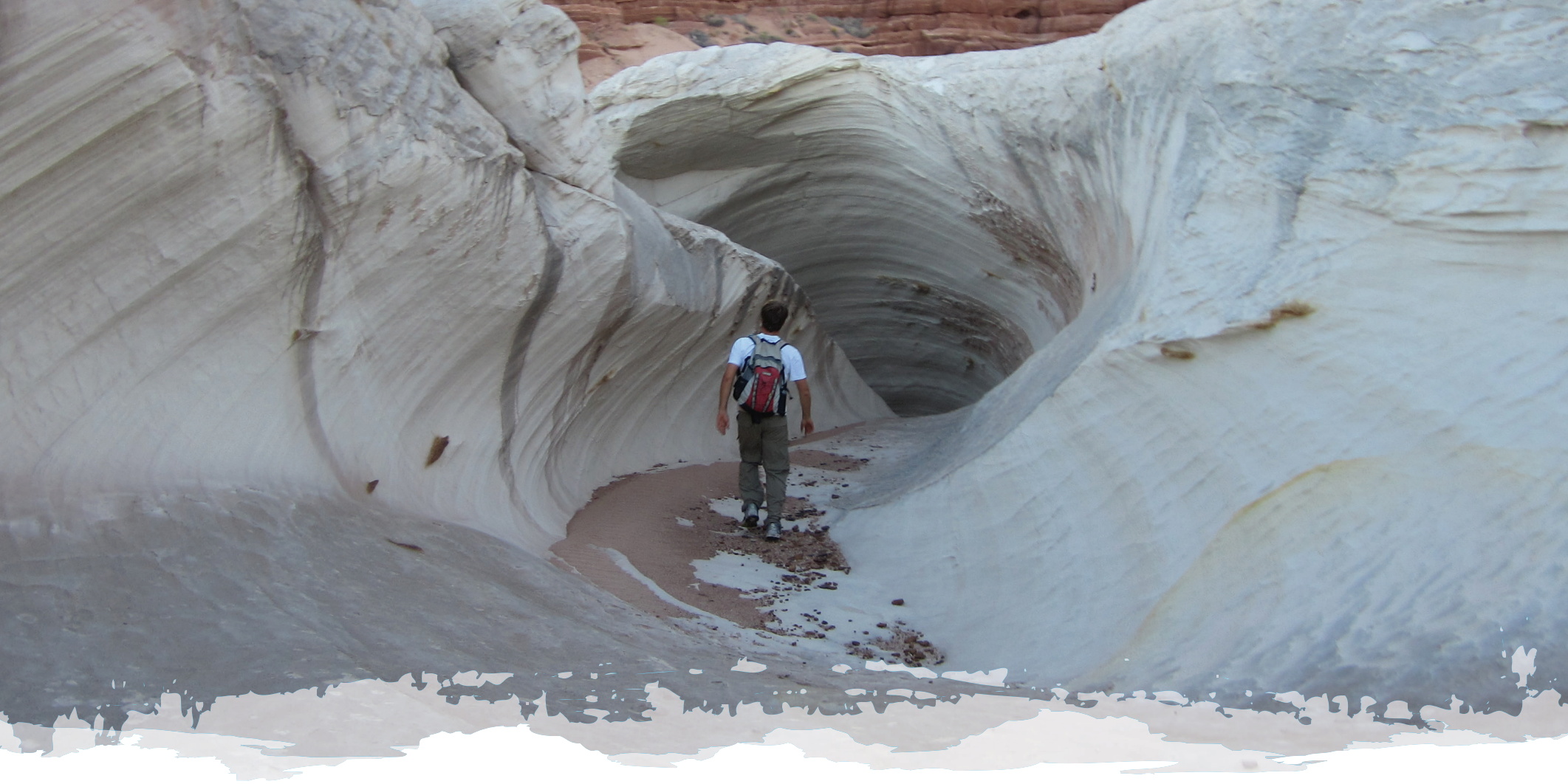

\title{
The Wind-Swept Nautilus, Enigmatic Clastic Pipes, and Toadstool Landforms: Geologic Features of the Paria Plateau
}

David F. Wheatley ${ }^{1,3}$, Winston M. Seiler ${ }^{2,3}$, and Marjorie A. Chan ${ }^{3}$

${ }^{1}$ Chevron Corporation, 1500 Louisiana St., Houston, TX 77002

${ }^{2}$ KCSI Aerial Patrol, 1105 Douglas St., Bakersfield, CA 93308

${ }^{3}$ Dept. Geology \& Geophysics, University of Utah, Salt Lake City, UT 84112

davidfwheatley@gmail.com

\section{Utah Geosites \\ 2019}

Utah Geological Association Publication 48

M. Milligan, R.F. Biek, P. Inkenbrandt, and P. Nielsen, editors

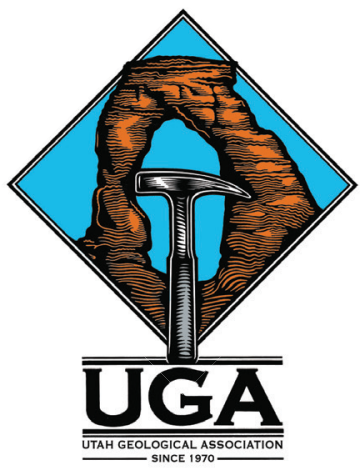

Cover Image: View into the Nautilus from its upper entrance. 


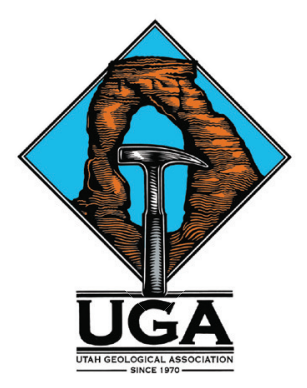

\section{Utah Geosites} 2019

\section{Utah Geological Association Publication 48}

M. Milligan, R.F. Biek, P. Inkenbrandt, and P. Nielsen, editors

Utah Geosites showcases some of Utah's spectacular geology, both little-known localities and sites seen by visitors to Utah's many national and state parks and monuments. The geosites reflect the interests of the many volunteers who wrote to share some of their favorite geologic sites. The list is eclectic and far from complete, and we hope that additional geosites will be added in the coming years. The Utah Geological Survey also maintains a list of geosites https://geology.utah.gov/apps/geosights/index.htm.

We thank the many authors for their geosite contributions, Utah Geological Association members who make annual UGA publications possible, and the American Association of Petroleum Geologists-Rocky Mountain Section Foundation for a generous grant for desktop publishing of these geosite papers.

Design and desktop publishing by Jenny Erickson, Graphic Designer, dutchiedesign.com, Salt Lake City, Utah.

This is an open-access article in which the Utah Geological Association permits unrestricted use, distribution, and reproduction of text and figures that are not noted as copyrighted, provided the original author and source are credited. See the Utah Geological Association website, www.utahgeology.org, and Creative Commons https://creativecommons.org/licenses/by/4.0/ for details.

Suggested citation for this geosite:

Wheatley, D.F., Seiler, W.M., and Chan, M.A., 2019, The windswept nautilus, enigmatic clastic pipes, and toadstool landforms-geologic features of the Paria Plateau, in Milligan, M., Biek, R.F., Inkenbrandt, P., and Nielsen, P., editors, Utah Geosites: Utah Geological Association Publication 48, 11 p., https://doi.org/10.31711/geosites.v1i1.67.

\section{Presidents Message}

I have had the pleasure of working with many different geologists from all around the world. As I have traveled around Utah for work and pleasure, many times I have observed vehicles parked alongside the road with many people climbing around an outcrop or walking up a trail in a canyon. Whether these people are from Utah or from another state or country, they all are quick to mention to me how wonderful our geology is here in Utah.

Utah is at the junction of several different geological provinces. We have the Basin and Range to the west and the Central Utah Hingeline and Thrust Belt down the middle. The Uinta Mountains have outcrops of some of the oldest sedimentary rock in Utah. Utah also has its share of young cinder cones and basaltic lava flows, and ancient laccoliths, stratovolcanoes, and plutonic rocks. The general public comes to Utah to experience our wonderful scenic geology throughout our state and national parks. Driving between our national and state parks is a breathtaking experience.

The "Utah Geosites" has been a great undertaking by many people. I wanted to involve as many people as we could in preparing this guidebook. We have had great response from authors that visit or work here in the state. Several authors have more than one site that they consider unique and want to share with the rest of us. I wanted to make the guidebook usable by geologists wanting to see outcrops and to the informed general public. The articles are well written and the editorial work on this guidebook has been top quality.

I would like to personally thank Mark Milligan, Bob Biek, and Paul Inkenbrandt for their editorial work on this guidebook. This guidebook could not have happened without their support. I would like to thank Jenny Erickson for doing the great desktop publishing and the many authors and reviewers that helped prepare the articles. Your work has been outstanding and will certainly showcase the many great places and geology of Utah. Last, but not least, Thank you to the American Association of Petroleum Geologists, Rocky Mountain Section Foundation for their financial support for this publication.

Guidebook 48 will hopefully be a dynamic document with the potential to add additional "geosites" in the future. I hope more authors will volunteer articles on their favorite sites. I would like to fill the map with locations so that a person or family looking at the map or articles will see a great location to read about and visit. Enjoy Guidebook 48 and enjoy the geology of Utah.

Peter J. Nielsen

2019 UGA President 


\section{INTRODUCTION}

The Colorado Plateau occupies much of the southwestern United States including portions of Arizona, Colorado, Utah, and New Mexico. This region presents unobstructed views from mesa tops, beautifully colored soils, lone standing buttes, and canyons cut thousands of feet deep. The Colorado Plateau represents a well-preserved window into the Earth's history. Today, the rocks of the Colorado Plateau lie roughly horizontally, as they were deposited hundreds of millions of years ago. The Plateau's rise has motivated rivers, in their downhill progress, to carve innumerable canyons. These river canyons allow any nature-lover the opportunity to gaze at 100s of millions of years of geologic history.

Within the larger Colorado Plateau, the Paria Plateau straddles the Utah and Arizona borders, and includes the Vermilion Cliffs National Monument, the Paria Canyon-Vermilion Cliffs Wilderness Area, and the southern extent of the Grand Staircase Escalante National Monument (GSENM; pre-2018 boundaries). The Paria Plateau is best known for spectacularly colored, wind-sculpted features such as Coyote Buttes and "The Wave," where vivid colors accent cross-strata resembling a cresting ocean wave. The Plateau is also recognized for the geologically notable Vermilion Cliffs, Buckskin Gulch slot canyon, White Pocket area, and the Paria River Canyon. Although only two, dual-lane highways circumvent the plateau, several wash-boarded gravel and deeply mud-rutted roads allow access to its interior. From these dirt roads, a few sandy, four-wheel drive paths diminish as they extend and branch into the plateau's interior. Overall, the Paria Plateau is a relatively quiet and little-visited wilderness.
On the northern portion of the Paria Plateau, a small but unique drainage into the Paria River highlights some of the unique geologic character of the region (figure 1A). Near the White House Campground trailhead, a starting point for backpacking and hiking the Paria River Canyon, one finds two exceptional features: (1) the Nautilus, which resembles the twisting contours of a nautilus seashell, and (2) world-class examples of peculiar sandstone columns, termed clastic pipes. Further up this drainage, on the northern side of U.S. Highway 89 , there is a spectacular collection of hoodoos and toadstools - balanced rocks atop pedestals of sedimentary rock (figure 1A).

These geosites provide both natural beauty and geologic insight into the history of this breathtaking landscape.

\section{STUDY AREA AND LOCALITY INFORMATION}

The specific features discussed in this paper are located on the northern end of the Paria Plateau. The Nautilus and several of the clastic pipe localities (here termed pipe sites 1 and 2) are south of U.S. Highway 89 and east of the Paria River near the White House Campground (figure 1). These sites can be accessed via a short hike up the dry riverbed from the graded dirt road that runs between the Paria Contact Station and White House Campground. Pipe sites 3 and 4 also occur among the washes and cliffs to the southeast along the river and can be accessed via dirt roads from Big Water, Utah, and Cottonwood Wash Road, about 3.1 miles $(5 \mathrm{~km})$ east of the Paria Contact Station. To explore these worldclass examples head south on Cottonwood Wash Road from U.S. Highway 89 for about 5.5 miles $(8.8 \mathrm{~km})$ and turn right, proceed 0.4

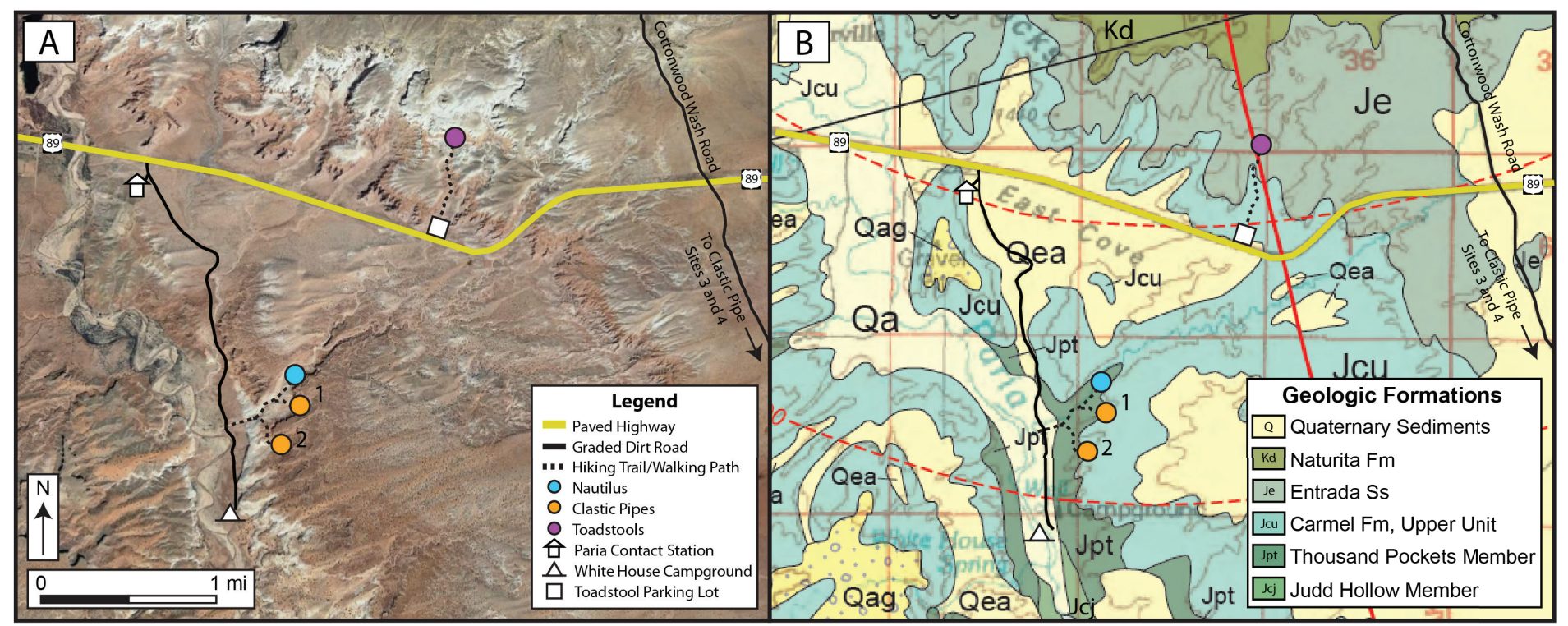

Figure 1. The Nautilus, clastic pipes, and toadstools can all be viewed in a relatively small region of the northern Paria Plateau near the Paria Contact Station. The Nautilus (blue circle) lies up a dry riverbed and can be accessed from a graded dirt road that runs between the Paria Contact Station and the White House

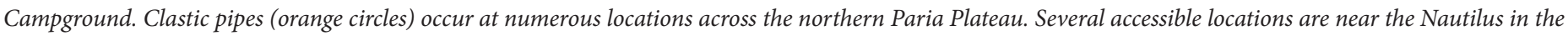

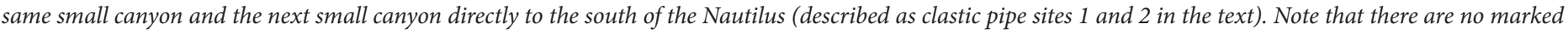

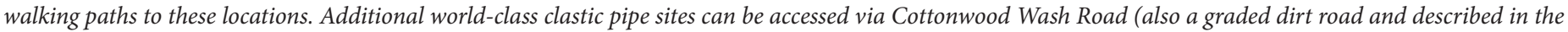

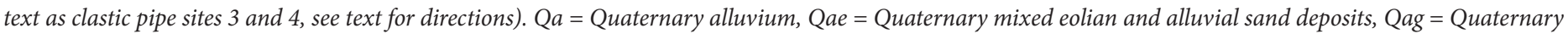
alluvial gravels. A. Base image (c) Google Earth. Image date: 2018. B. Geologic map modified from Doelling and Willis, 2006. 
miles $(0.7 \mathrm{~km})$ until you reach a set of power lines, then turn right. Pipe site 3 is along this road 1.3 miles $(2.1 \mathrm{~km})$ from the turn. Pipe site 3 is within a dry riverbed to the left of the road at the junction with another dirt road. To access pipe site 4 continue along the road 2.1 miles $(3.4 \mathrm{~km})$ taking a left, then right, then left as you encounter forks in the road. The site is to the right of the road with pipes located along the cliffs and benches of the Middle Jurassic Carmel Formation. In addition to the examples on the Paria Plateau, Kodachrome Basin State Park (about 31 miles [50 km] north) hosts several excellent examples of large clastic pipes (Baer and Steed, 2010).

To access the toadstools travel about 1.5 miles $(2.4 \mathrm{~km})$ east along U.S. Highway 89 from the Paria Contact Station to a dirt parking lot on the north side of the highway. From the parking lot there is a short, marked trail that leads to the toadstools.

\section{GPS Localities}

The Nautilus: $37.089615^{\circ}-111.885812^{\circ}$

Clastic pipes: $37.088191^{\circ},-111.884580^{\circ}$ (Site 1); $37.084979^{\circ}$

$-111.885801^{\circ}$ (Site 2); $37.041435^{\circ}-111.824171^{\circ}$ (Site 3);

$37.055681^{\circ}-111.853802^{\circ}$ (Site 4 )

Toadstools: $37.108227^{\circ}-111.870886^{\circ}$

\section{REGIONAL STRATIGRAPHY AND GEOLOGIC HISTORY}

The major rock units of the Paria Plateau include the sedimentary Lower Jurassic Navajo Sandstone, Middle Jurassic Carmel Formation, and Middle Jurassic Entrada Sandstone. These three Jurassic units span roughly 30 million years of geologic history and were deposited between about 190 and 160 million years ago (figures $1 \mathrm{~b}$ and 2) (Doelling and others, 1989; Peterson, 1994; Blakey and others, 1996; Caputo, 2010).

\section{The Lower Jurassic Navajo Sandstone}

The Navajo Sandstone is one of the most easily distinguished formations of the Colorado Plateau. The Navajo Sandstone can form impressive cliffs over 2000 feet $(600 \mathrm{~m})$ tall and the formation covers an extensive region from Zion National Park to the Vermilion Cliffs through Glen Canyon to Arches and Canyonlands National Parks (Kocurek and Dott, 1983, Kocurek, 2003).

The Navajo Sandstone was deposited about 190 million years ago (Peterson and Pipiringos, 1979; Rahl and others, 2003) as a giant, arid, eolian (wind-blown) sand sea, or erg, much like the modern Saharan Desert erg. At its original extent, the Navajo likely covered an area two and a half times its current reach-about 255,000 miles $^{2}\left(660,000 \mathrm{~km}^{2}\right)$ (Kocurek, 2003; Blakey, 2013). Though reduced over the millennia by erosion, the Navajo is still the world's largest eolian deposit (Kocurek, 2003). To put its size into perspective, it has been estimated that the volume of sand deposited by the Navajo erg was between 14,400 to 33,600 miles $^{3}(60,000-$

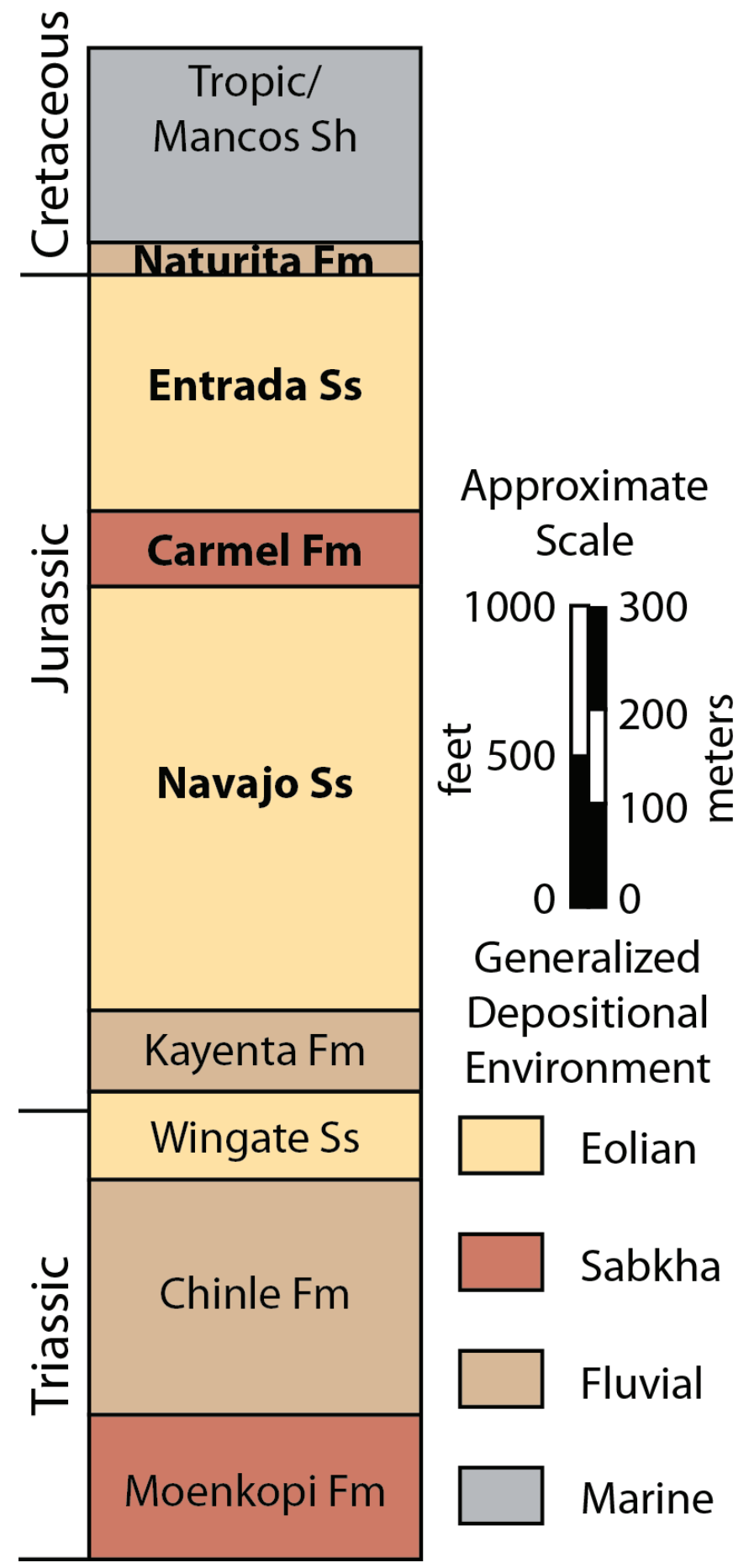

Figure 2. Regionally, the Paria Plateau consists of a set of sedimentary rock units dominantly deposited in dryland continental environments (e.g., eolian, sabkha, and fluvial deposits). The Nautilus and clastic pipes occur within the Middle Jurassic Carmel Formation in the Thousand Pockets and Paria River Members, respectively. The toadstools occur within the Middle Jurassic Entrada Sandstone with Cretaceous Naturita Formation (previously termed the Dakota Formation) caps. Bolded formation names indicate formations in and around the geosites. The Romana Sandstone and Morrison Formation are absent with the Naturita Formation sitting directly on the Entrada Sandstone (see figure 1B; Doelling and Willis, 2006). The majority of the Paria Plateau is the Navajo Sandstone and younger units; however, older formations are exposed along the Plateau's flanks. Ss = sandstone; Sh=Shale; Ls = Limestone. Stratigraphic data modified from Ron Blakey's Colorado Plateau Geosystems website. 
$140,000 \mathrm{~km}^{3}$ ), the equivalent of 6 to 14 million years of continuous deposition at the mouth of the Mississippi River (Kocurek, 2003). In recreating the paleogeography of the Navajo erg, Rahl and others (2003) envision that most of the Navajo sands were derived from the ancestral Appalachian Mountains. They propose rivers carrying sediment from their headwaters in the ancient Appalachians to the western shores of the supercontinent Pangea, flowing north of the Ancestral Rockies. From here, the river sand was blown to the south to form the Navajo erg.

On the Paria Plateau, the Navajo Sandstone is a fine- to medium-grained sandstone with large beds of cross-stratified laminae (internally inclined, thin sandstone layers) that represent the sloping face of the ancient dune deposits. The formation can be colored in a combination of whites, oranges, yellows, tans, and reds depending on the types and amount of iron-rich minerals present in the sandstone. The Navajo Sandstone is the sculpted rock of the Coyote Buttes and forms the prominent cliffs of The Dive, Steamboat Rock, and White Pocket. Locally, the Navajo Sandstone has been studied extensively as a record of diagenetic (i.e., post-depositional) fluid flow as preserved in its coloration (Eichhubl and others, 2004; Beitler and others, 2005; Nielsen and others, 2009; Nielsen and Chan, 2010; Potter and Chan, 2011; Seiler and Chan, 2014), as an analog to surficial weathering processes on Mars (Chan and others, 2008; Chan and others, 2011), and for its preservation of dinosaur footprints (Irmis, 2005; Loope, 2006).

\section{The Middle Jurassic Carmel Formation}

Unconformably deposited atop the Navajo Sandstone is the Carmel Formation. This contact (i.e., surface between two formations), termed the J1 unconformity, represents a significant period of erosion that formed a paleotopography. Regionally, the Carmel Formation is composed of inter-fingered layers of limestone, sandstone, shale, and gypsum and is found throughout southern Utah (Caputo, 2010). At these geosites, the Carmel Formation crops out as small (about 100 feet [30 m]) cliffs of variegated red, pink, and white, horizontally bedded sandstone layers.

The Carmel Formation can be subdivided into five members (i.e., groupings of similar rock types). From oldest to youngest they are: (1) the Judd Hollow Member, (2) the Thousand Pockets Member, (3) the Crystal Creek Member, (4) the Paria River Member, and (5) the Winsor Member (Sprinkel and others, 2011; Doelling and others, 2013). For the purposes of this paper, we use the stratigraphy put forth by Doelling and others (2013), which includes the Thousand Pockets Member in the Carmel Formation; however, the Thousand Pockets Member was previously included as a tongue of the Navajo Sandstone or the Page Sandstone (Phoenix, 1963; Pipiringos and O’Sullivan, 1978) and some geologic maps and workers still use this designation. These members represent the cyclic rise and fall of an inland sea and the corresponding advance and retreat of an arid coastal plain and nearby dune field (Jones and Blakey, 1997). Except for the Judd Hollow Member, all Carmel Formation members are exposed at the main study sites.

\section{The Middle Jurassic Entrada Formation and Cretaceous Naturita Formation}

The Entrada Formation conformably lies above the Jurassic Carmel Formation and is another eolian unit, similar to the Navajo Sandstone, but with much more variability. Its sandy beds represent dunes and marginal beach deposits. It is generally softer than the Navajo Sandstone and is not such a prominent cliff former. Regionally, there are intervening units between the Entrada Formation and the younger Cretaceous Naturita Formation (previously termed the Dakota Formation). However, locally, the intervening units are absent because of erosion resulting in isolated Naturita blocks of ancient river-deposited coarse-grained to pebbly sandstone uncomfortably resting on top of spires of exposed Entrada Sandstone.

\section{GEOLOGIC FEATURES OF THE PARIA PLATEAU}

\section{The Nautilus}

\section{Observations}

The Nautilus is a short, twisting slot canyon formed in the approximate shape of a logarithmic spiral, reminiscent of the cutaway of a chambered nautilus - the marine cephalopod (figures 3 and 4). It extends approximately 100 feet $(30 \mathrm{~m})$ in length, is 16 feet $(5 \mathrm{~m})$ wide at is upper opening, and 3 feet $(1 \mathrm{~m})$ in width in its narrowest central portion. The slot is cut to an approximate depth of 33 feet $(10 \mathrm{~m})$ and steepens in slope as it twists from top to bottom (note: visitors should respect the delicate nature of the Nautilus and take care to preserve the feature when exploring its natural beauty).

The Nautilus spirals through the bleached white, eolian cross-bedded Thousand Pockets Member of the Carmel Formation. Several orange- to yellow-colored inch- to sub-inch- ( $\mathrm{mm}$ to $\mathrm{cm}$-scale) thick Liesegang bands-repeating stripes of minerals (iron oxides) that streak across and overprint the original strata-and isolated iron cemented concretionary masses decorate the feature. Sub-quarter inch (mm-scale) concretions are evenly dispersed in the lower portion, near the outflow of the Nautilus into the main wash.

Though the immediate area displays fracturing in the sandstone, the Nautilus is not correlated with any obvious local or regionally oriented joint set or fracture pattern. Little capacity for water collection exists upstream of the Nautilus feature; the drainage area above the Nautilus occupies less than $2420 \operatorname{yards}^{2}\left(2023 \mathrm{~m}^{2}\right)$.

Prominent throughout the Nautilus, on horizontal, vertical, and sloped faces, are inch to sub-inch (cm-scale) erosional, stepped tread and riser features. The riser portions of these features are consistently oriented towards the upper entrance of the Nautilus. 
Tread and riser features visually resemble sastrugi-irregular ridges carved into hard snow by wind (Loope and others, 2008). Parallel-oriented fluting in the sandstone is noted downstream of erosionally resistant concretionary features and other protuberances within the core of the Nautilus.

\section{Interpretations}

Narrow and twisting slot canyons are common in sandstone on the Colorado Plateau. Although most slot canyons are the product of repeated, powerful floods exploiting joints in the sandstone, wind is a less recognized, but nevertheless significant erosive mechanism in a smaller subset of slot canyons. Wind carrying abrasive sand grains is the primary erosional force that has shaped the Nautilus.

While the spiral feature may have been initiated by water exploiting a weakness in the sandstone, there is little evidence to suggest that water remains the predominant erosional force-the drainage above the entrance is extremely limited, there is no evidence of runnels or depositional outflow indicative of flowing water at the exit of the Nautilus, and horizontal surfaces do not display channeling by water at low points. Instead, the presence of tread and riser features and fluting downwind of concretionary protuberances are prominent ventifacts documenting the erosive force of wind in shaping the Nautilus (figures 3 and 4). The orientation of these features is consistent with wind channeled up the larger drainage, locally from the southwest, and being directed into the Nautilus to enter from the south at its upper opening. Loope and others (2008) describe sand-carrying winds as the primary active abrasive mechanism for the shaping of the Wave, another photogenic wind shaped feature approximately 9 miles $(14 \mathrm{~km})$ southwest on the Paria Plateau. They document and define erosional treads and risers cut by the impact of wind-blown sand undercutting fine microbial crusts lying just under the sandstone surface.
The subtle Liesegang coloration and presence of iron-oxide concretions are illustrative of past changes in groundwater chemistry (e.g., a reducing/oxidizing fluid boundary) while the rock was still buried (Wang and others, 2015). These chemical reaction fronts and associated coloration have been described extensively by Beitler and others (2005), Potter and Chan (2011), and Seiler and Chan (2014), although the precise timing of these fluid movements remain a mystery.

\section{Clastic Pipes}

\section{Observations}

Clastic pipes form vertical sandstone columns that typically contrast in color and texture from the host sandstone (figures 5A-D). The white sandstone pipes stand out against a background of red, layered, sandstone host rocks that contain mud cracks, root casts, and cross-beds. Interspersed between the layered sandstone strata, the Carmel Formation has several beds of volcanic clasts and fragments, and multiple thin volcanic ash layers. The pipes are feet (10s of centimeters to meters) in diameter and are composed of quartz-rich sand and volcanic fragments similar to the surrounding host rock. However, pipes have internal, radial grading with outward coarsening (i.e., they have a consistent outward increase in grain size). Many pipes have an outer rind with a 0.5 to 2 inches $(1-5 \mathrm{~cm})$ rind of coarser grained sediment. Pipes also have significant diagenetic, fluid-related characteristics including bleached white rings or "halos" surrounding many pipes. Pipes also have numerous calcite concretions or nodules that form preferentially on the outer portion of the pipes.

The clastic pipes occur across an approximately 100 foot $(30 \mathrm{~m})$ thick stratigraphic interval in the Paria River Member of the Carmel Formation. Two dated volcanic ash layers approximately 3 feet $(1 \mathrm{~m})$ below and 16 feet $(5 \mathrm{~m})$ above the interval provide lower and upper bounds on the sediments with ages of about 166 million years and about 164 million years, respectively (Kowallis and others, 2020). Pipes emanate from a single "source" bed,

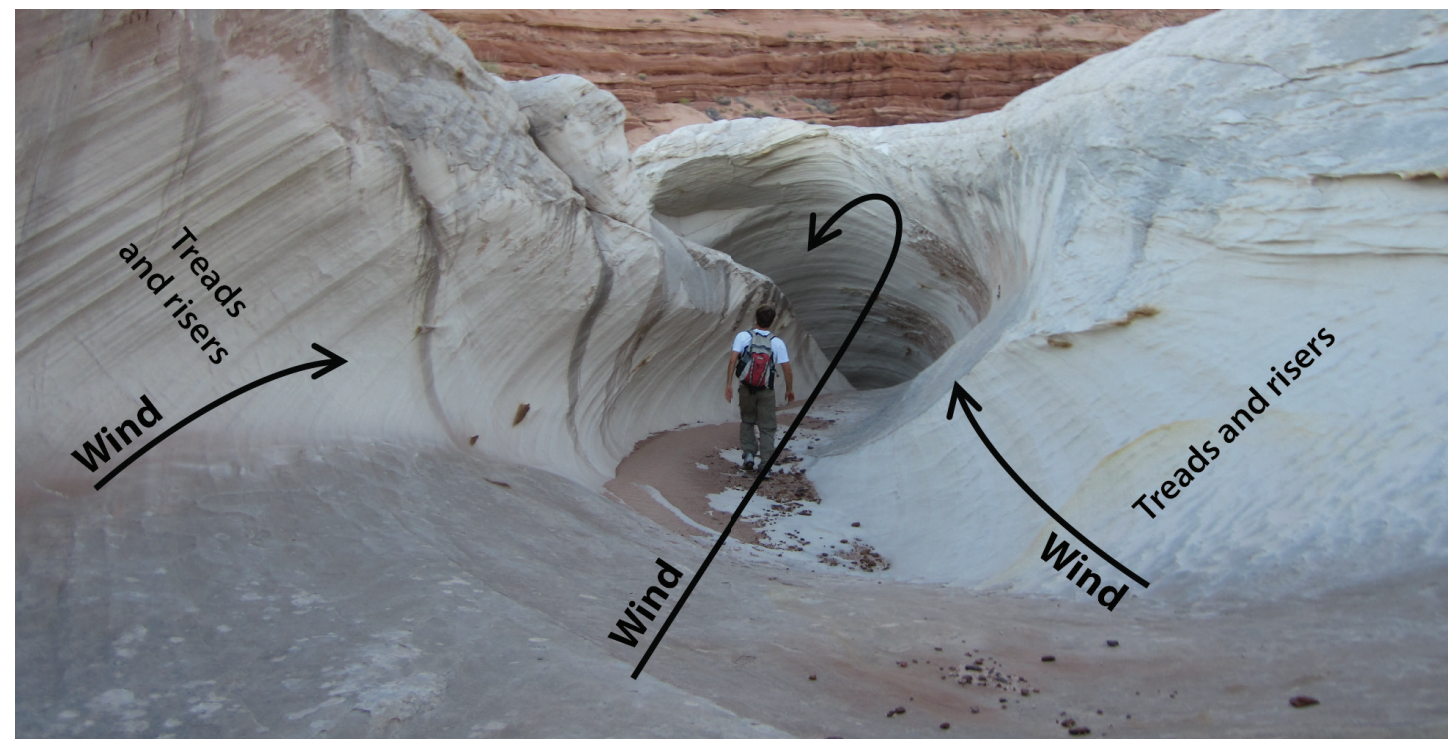

Figure 3. View into the Nautilus from its upper entrance. Arrows indicate the direction of wind, funneled into the Nautilus from the south. Tread and riser features, indicative of erosion by wind, are found at this upper entrance. The Nautilus occurs in the Thousand Pockets Member of the Carmel Formation. 


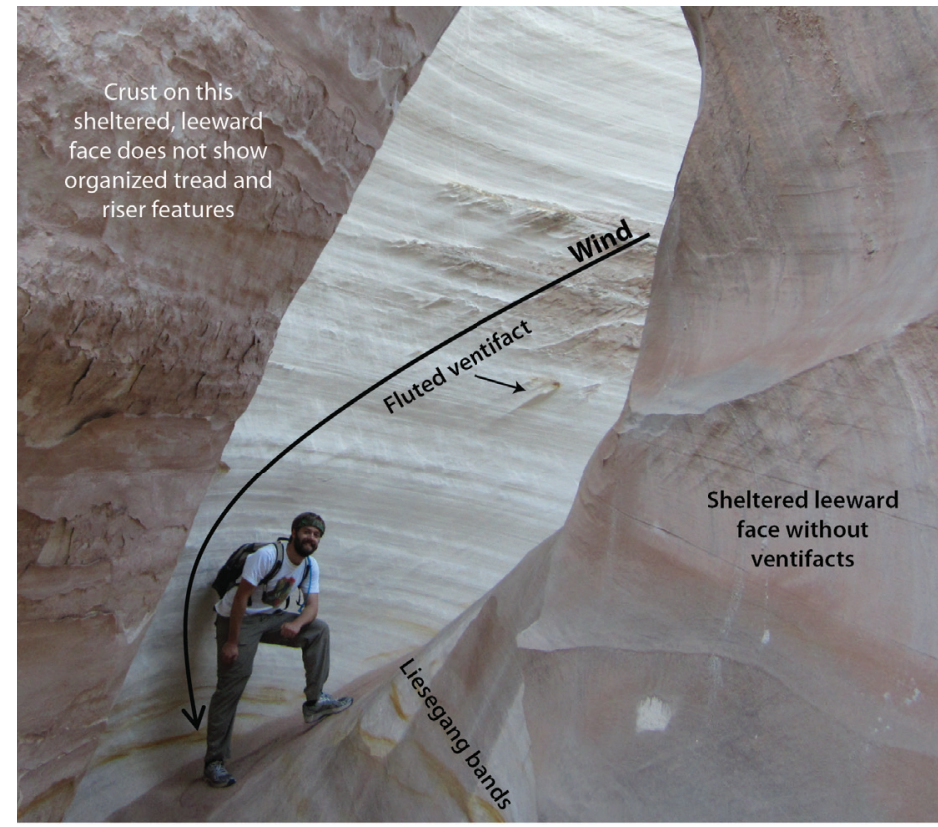

Figure 4. The central portion of the Nautilus displays fluted ventifacts downwind of erosionally resistant concretions, while sheltered, leeward faces of the Nautilus lack features indicative of erosion by wind. Liesegang bands and micro concretions cross cut stratigraphy, and occur in the lowermost portions of the Nautilus. The Nautilus occurs in the Thousand Pockets Member of the Carmel Formation.

move upward through the 100 feet $(30 \mathrm{~m})$ stratigraphic interval, and flare outwards as they terminate. Syn-sedimentary faulting and folding further deformed the pipe-bearing interval during to shortly after deposition. The faulting is particularly concentrated around in the pipes and the folding occurs most commonly just above the source layer.

\section{Interpretations}

The presence of root casts, mud cracks, and cross-bedded strata along with the regional geology indicate that the pipes formed on an arid coastal plain, also called a sabkha. The sabkha was located between an evaporative, shallow inland sea and a dune field and was dissected by ephemeral streams (i.e., water only flowed for a portion of the year). These marginal, coastal environments are characterized by low biological productivity, wetting and drying (e.g., mud cracks and gypsum formation), and a high water table. Clastic pipes form through a process called fluidization (figure 5E) (Owen, 1987; Wheatley and others, 2016; Wheatley and Chan, 2018). Fluidization occurs through the rapid, violent release of pressurized, water-saturated sediments in the subsurface by a trigger such as an earthquake, sediment loading, or a sudden flood (Obermeier, 1996; Owen and Moretti, 2011). The water-saturated sabkha sediments with interbedded sands (i.e., the sand source for the pipes) and muds (i.e., the seal to allow pressurization of the sand layers) provide an ideal pipe-forming environment.

Pipe formation requires a specific set of conditions. (1) The sandy source layer is deposited below a fine-grained mud layer (figure
$5 \mathrm{E}$, panel 1). The mud layer acts as a seal above the source layer. (2) A trigger (i.e., a rapid energy release, examples include an earthquake, landslide, flood, etc.) then initiates liquefaction and pressurizes the source layer. (3) Once the pressure in the source layer rises above the sealing capacity of the mud layer, the muddy seal fails resulting in the catastrophic release of pressure (figure 5E, panel 2). (4) The fluid moves rapidly to the surface causing fluidization and entraining sediment. At the surfaces the pipes erupt as sand volcanoes and form the flared horizons observed in outcrop. The process of fluids moving upward through the host sediment sorts the sediment giving pipes their characteristic grading. This process is incredibly violent and results in the faulting and folding of the surrounding host sediment. (5) After pipe formation the pipes de-water causing a reduction in volume of the pipe sediment and the formation of "relaxation" structures such as inward (i.e., pipe-ward) dipping faults (figure 5E, panel 3). (6) After continued deposition and erosion/reworking of the above-ground portions of the sand volcanoes, diagenetic fluids moved through the pipes bleaching them white and leaving behind carbonate concretions/ nodules (figure 5E, panel 4). (7) Finally, after the sediment turned to rock and was uplifted, the better cemented pipes eroded out in positive relief as sandstone spires (figure 5E, panel 5).

\section{Toadstools and Hoodoos}

\section{Observations}

Colorful, tall, towering toadstools and hoodoos are visible on an easy short hike farther upstream from the Nautilus and clastic pipes (but most easily accessed directly from U.S. Highway 89) (figure 6). Delicately balanced hard, resistant rock caps of Cretaceous Naturita Formation rest on weaker more easily eroded narrow stalks of Entrada Sandstone (figure 6). The mushroom and toadstool landforms have the erosional-resistant cap, while the hoodoos are erosional towers without the caps. Together, these comprise an enchanting fairyland scene.

\section{Interpretations}

After the sedimentary deposits were buried and lithified, later uplift subjected the formations to forces that created joint and fracture patterns (i.e., preferential zones of weakness), somewhat like checkerboard lines and squares. Through time, wind and water worked away at the sides of the chunky Cretaceous Naturita Formation caps resulting in isolated blocks resting on the softer, older, white and red Jurassic Entrada Sandstone (Doelling and others, 1989; Doelling and Willis, 2006). The Entrada Sandstone is slightly protected by the Naturita caps, but over a long period of time, the softer Entrada Sandstone Jurassic eroded away and is undercut beneath the resistant cap. What is left are the dramatic spires that resemble a mushroom shape of perched and balanced boulders in a landscape of pedestals and towers (figure 6). 


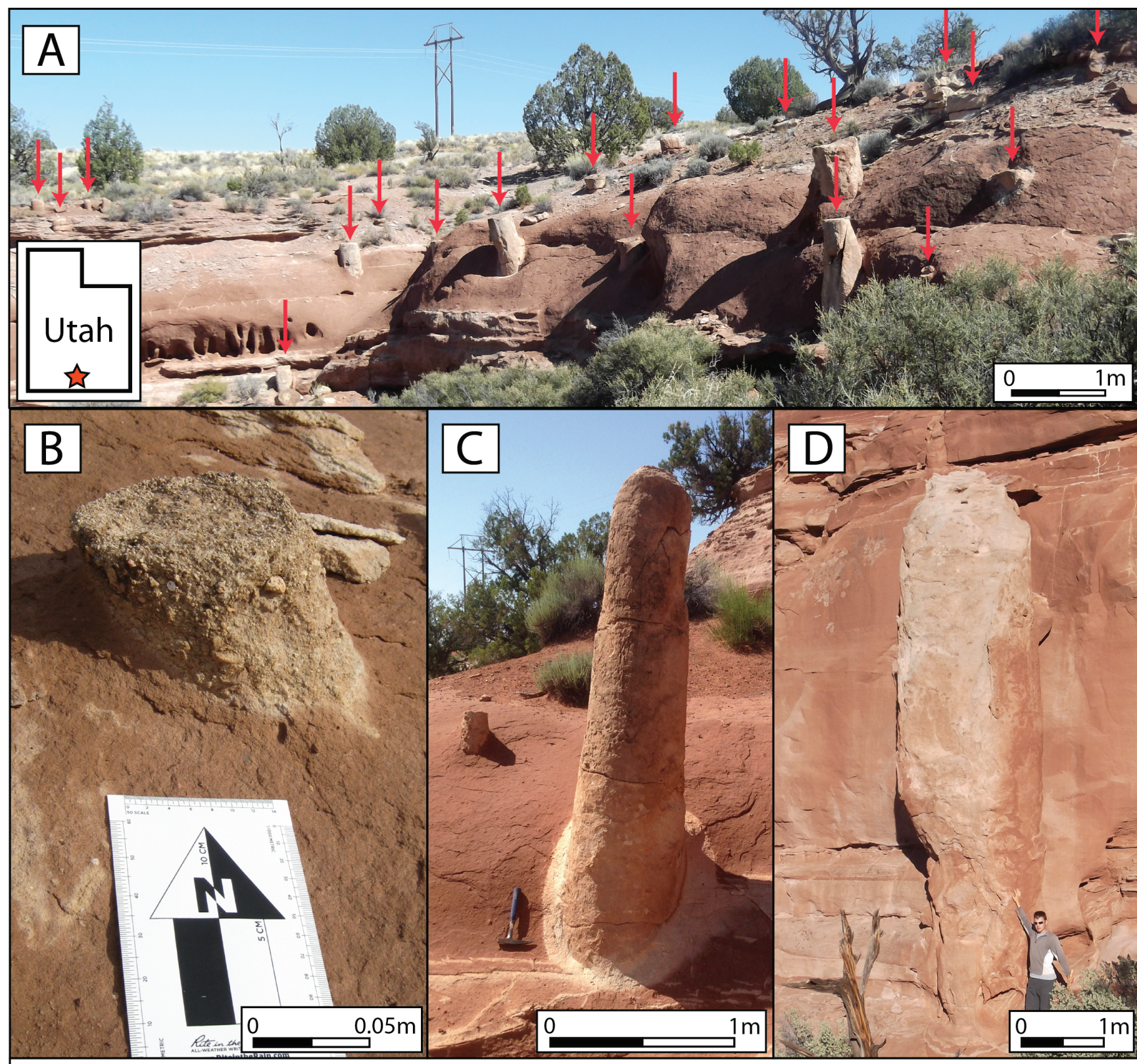

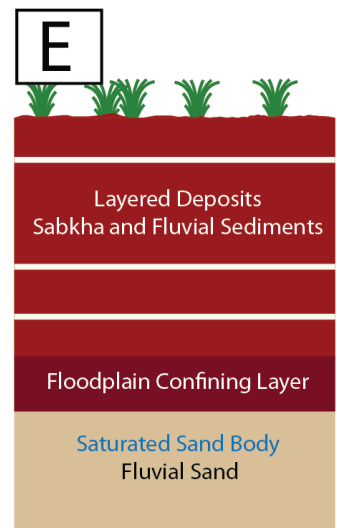

(1) Initial Conditions

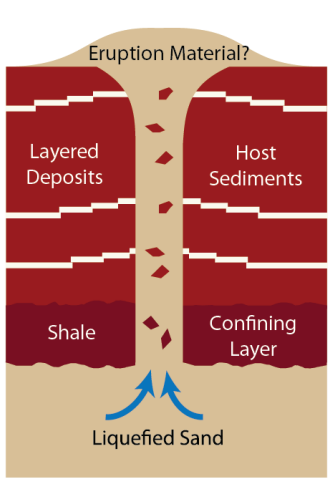

(2) Pipe Emplacement

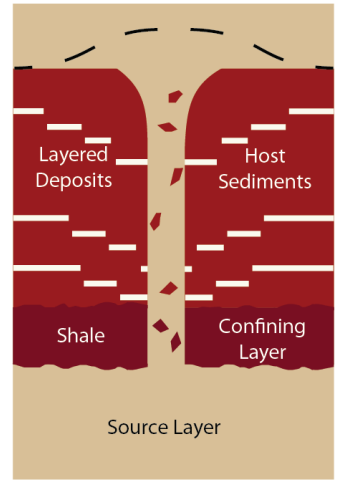

(3) Dewatering/Deposition (4) Diagenesis

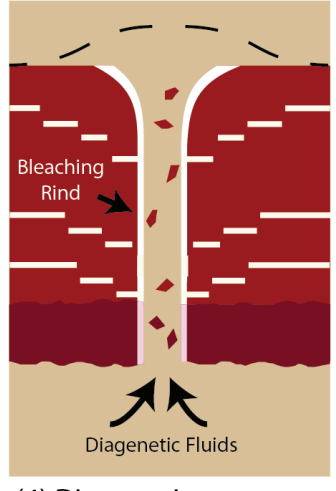

(5) Modern Landscape

Figure 5. Clastic pipes weather out among the washes and cliffs of the Carmel Formation $(A, B, C$, and $D)$. The white pipes stand out against a red host rock (Paria River Member of the Carmel Formation). These images show two additional sites (sites 3 and 4) referenced in the caption of figure 1. Panel $E$ details the formation process of clastic pipes (see section on interpretation). Pipes form through liquefaction and fluidization (i.e., the violent release of pressurized subsurface fluids) (modified from Wheatley and others, 2016). 


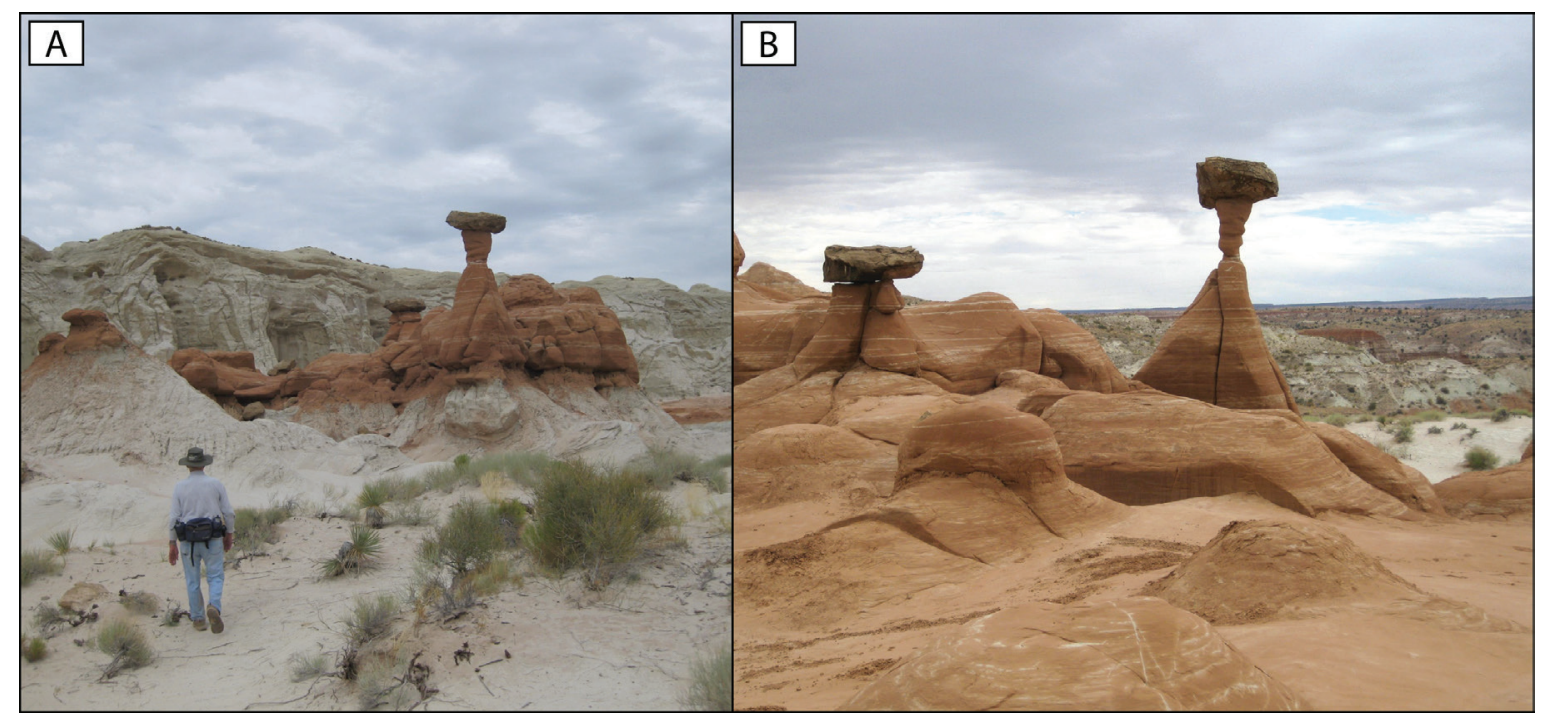

Figure 6. These toadstools are slender columns of the Middle Jurassic Entrada Sandstone with an erosionally resistant cap of Cretaceous Naturita Formation. These whimsical features resemble toadstools or mushrooms. In some cases, the erosionally resistant cap is no longer present leaving a slender spire of rock termed a hoodoo.

\section{CONCLUSIONS}

The Paria Plateau provides an excellent outdoor classroom to explore over 200 million years of Earth's history and exposes ancient wonders through intricate erosion. The arid landscape of the Jurassic period resulted in the deposition of broad eolian sand seas and coastal plains (i.e., sabkhas). These strata were subsequently deformed by fluidization to form sand volcanoes, and were later colored and cemented by iron rich fluids to form a vertical tapestry of reds, oranges, and yellows. Then, as the Colorado Plateau was uplifted, water and wind formed the beautiful canyons and features like the Nautilus and revealed the clastic pipes as sandstone spires. Modern erosion acting on sediments with differing resistance to weathering has formed the towering and precarious toadstools and hoodoos. These geologic features need to be protected for generations to come so that others can come learn and marvel.

\section{ACKNOWLEDGEMENTS}

We thank Doug Sprinkel, Mark Hansford, Mark Milligan, and Bob Biek for their helpful reviews of this manuscript. This paper is the result of geologic field studies completed at the University of Utah, with support from the National Science Foundation, National Aeronautics and Space Administration, the GDL Foundation, the Rocky Mountain Association of Geologists, the American Association of Petroleum Geologists, the Geologic Society of America, and the Wheaton College Scholastic Honors Society.

\section{REFERENCES}

Baer, J.L., and Steed, R.H., 2010, Geology of Kodachrome Basin State Park, Utah, in Sprinkel, D.A., Chidsey, T.C., Jr., and Anderson, P.A., Geology of Utah's Parks and Monuments: Utah Geological Association Publication 28 (3rd edition), p. 467-482.

Beitler, B., Parry, W.T., and Chan, M.A., 2005, Fingerprints of fluid flow-chemical diagenetic history of the Jurassic Navajo
Sandstone, southern Utah, USA: Journal of Sedimentary Research, v. 75, no. 4, p. 547-561.

Blakey, R.C., Havholm, K.G., and Jones, L.S., 1996, Stratigraphic analysis of eolian interactions with marine and fluvial deposits, Middle Jurassic Page Sandstone and Carmel Formation, Colorado Plateau, USA: Journal of Sedimentary Research, Section B: Stratigraphy and Global Studies, v. 66, no. 2. p. 324-342.

Blakey, R.C., 2013, Early Jurassic Map, Paleogeography of Southwestern North America Series: Online, www.deeptimemaps. com, accessed Feb. 6, 2019.

Caputo, M.V., 2010, Geology and sedimentary highlights of the Paria Canyon-Vermilion Cliffs Wilderness, Utah and Arizona, in Sprinkel, D.A., Chidsey, T.C., Jr., and Anderson, P.A., Geology of Utah's Parks and Monuments: Utah Geological Association Publication 28 (3rd edition), p. 559-587.

Chan, M.A., Nicoll, K., Ormö, J., Okubo, C., and Komatsu, G., 2011, Utah's geologic and geomorphic analogs to Mars-an overview for planetary exploration: Geological Society of America Special Papers, v. 483, p. 349-375.

Chan, M.A., Yonkee, W.A., Netoff, D.I., Seiler, W.M., and Ford, R.L., 2008, Polygonal cracks in bedrock on Earth and Marsimplications for weathering: Icarus, v. 194, no. 1, p. 65-71.

Doelling, H.H., Davis, F.D., and Brandt, C.J., 1989, The geology of Kane County, Utah-geology, mineral resources, geologic hazards: Utah Geological and Mineral Survey Bulletin 124, p. 192.

Doelling, H.H., and Willis, G.C., 2006, Geologic map of the Smokey Mountain 30'x60' quadrangle, Kane and San Juan Counties, Utah, and Coconino County, Arizona: Utah Geological Survey Map 213, 2 plates, scale 1:100,000.

Doelling, H.H., Sprinkel, D.A., Kowallis, B.J., and Kuehne, P.A., 
2013, Temple Cap and Carmel Formations in the Henry Mountains Basin, Wayne and Garfield Counties, Utah, in Morris, T.H., and Ressetar, R., editors, The San Rafael Swell and Henry Mountains Basin-geologic centerpiece of Utah: Utah Geological Association Publication 42, p. 279-318.

Eichhubl, P., Taylor, W.L., Pollard, D.D., and Aydin, A., 2004, Paleo-fluid flow and deformation in the Aztec Sandstone at the Valley of Fire, Nevada-evidence for the coupling of hydrogeologic, diagenetic, and tectonic processes: Geological Society of America Bulletin, v. 116, no. 9-10, p. 1120-1136.

Irmis, R.B., 2005, A review of the vertebrate fauna of the Lower Jurassic Navajo Sandstone in Arizona: Mesa Southwest Museum Bulletin, v. 11, p. 55-71.

Jones, L.S., and Blakey, R.C., 1997, Eolian-fluvial interaction in the Page Sandstone (Middle Jurassic) in south-central Utah, USA-a case study of erg-margin processes: Sedimentary Geology, v. 109, p., 181-198. doi:10.1016/S0037-0738(96)00044-9.

Kocurek G., and Dott R. H. Jr., 1983, Jurassic paleogeography and paleoclimate of the central and southern Rocky Mountain region, in Reynolds, M.W. and Dolly, E.D., editors, Mesozoic paleogeography of the West-Central United States, Rocky Mountain Paleogeography Symposium 2: Society of Economic Paleontologists and Mineralogists - Rocky Mountain Section, Denver, CO, p. 101-116.

Kocurek, G., 2003, Limits on extreme eolian systems: Sahara of Mauritania and Jurassic Navajo Sandstone examples, in Chan, M.A. and Archer, A., editors, Extreme Depositional Environments: Mega End Members in Geologic Time: Geological Society of America Special Paper 370, p. 143-156.

Kowallis, B.J., Sprinkel, D.A., Christiansen, E.H., Steed, S., and Wheatley, D.F., 2020, Rhyolite ignimbrite boulders and cobbles in the Middle Jurassic Carmel Formation of Utah and Arizona: Age, Composition, Transport, and Stratigraphic Setting: Geology of the Intermountain West, v. 7, no. 3, In press.

Loope, D.B., 2006, Dry-season tracks in dinosaur-triggered grainflows: Palaios, v. 21, no. 2, p. 132-142.

Loope, D.B., Seiler, W.M., Mason, J.A., and Chan, M.A., 2008, Wind scour of Navajo Sandstone at the Wave (central Colorado Plateau, USA): The Journal of Geology, v. 116, no. 2, p. $173-183$.

Nielsen, G.B., Chan, M.A., and Petersen, E.U., 2009, Diagenetic coloration facies and alteration history of the Jurassic Navajo Sandstone, Zion National Park and vicinity, southwestern Utah, in Tripp, B.T., Krahulec, K., and Jordon, J.J., editors, Geology and geologic resources and issues of western Utah: Utah Geological Association Publication 38, p. 67-96.
Nielsen, G.B., and Chan, M.A., 2010, Geologic map and coloration facies of the Jurassic Navajo Sandstone, Snow Canyon State Park and areas of Red Cliffs Desert Reserve, Washington County, Utah: Utah Geological Survey Open-File Report 561, scale 1:10,000.

Obermeier, S.F., 1996, Using liquefaction-induced features for paleoseismic analysis, in McCalpin, J., editor, Paleoseismology: San Diego, California, Academic Press, p. 331-396.

Owen, G., 1987. Deformation processes in unconsolidated sands: Geological Society of London Special Publication 29, p. 11-24, doi:10.1144/GSL.SP.1987.029.01.02.

Owen, G., and Moretti, M., 2011, Identifying triggers for liquefaction-induced soft-sediment deformation in sands: Sedimentary Geology, v. 235, p. 141-147, doi:10.1016/j.sedgeo.2010.10.003.

Peterson, F., and Pipiringos, G.N., 1979, Stratigraphic relations of the Navajo Sandstone to Middle Jurassic formations, southern Utah and northern Arizona: U.S. Geological Survey Professional Paper 1035-B, p. B1-B43.

Peterson, F. 1994. Sand dunes, sabkhas, streams, and shallow seas-Jurassic paleogeography in the southern part of the Western Interior Basin, in Caputo, M.V., Peterson, J.A., and Franczyk, K.J., editors, Mesozoic systems of the Rocky Mountain region, USA: Rocky Mountain Section, Society of Economic Paleontologists and Mineralogists, p. 233-272.

Pipiringos, G. N., and O’Sullivan, R. B., 1978, Principal unconformities in Triassic and Jurassic rocks, western interior United States-a preliminary survey: U.S. Geological Survey Professional Paper 1035-A, p. 29.

Phoenix, D.A., 1963, Geology of the Lees Ferry area, Coconino County, Arizona: U.S. Geological Survey Bulletin 1137, 86 p., 3 plates, scale 1:24,000.

Potter, S.L., and Chan, M.A., 2011, Joint controlled fluid flow patterns and iron mass transfer in Jurassic Navajo Sandstone, Southern Utah, USA: Geofluids, v. 11, p. 184-198.

Rahl, J.M., Reiners, P.W., Campbell, I.H, Nicolescu, S., and Allen, C.M., 2003, Combined single-grain (U-Th)/He and U/Pb dating of detrital zircons from the Navajo Sandstone, Utah: Geology, v. 31, no. 9, p. 761-764;

Seiler, W.M., and Chan, M.A., 2014, Coloration and diagenetic history of Jurassic Navajo Sandstone at Coyote Buttes, Paria Canyon-Vermillion Cliffs Wilderness, Utah and Arizona, in MacLean, J.S., Biek, R.F., and Huntoon, J.E., editors, Geology of Utah's Far South: Utah Geological Association Publication 43, p. 237-258. 
Sprinkel, D.A., Doelling, H.H., Kowallis, B.J., Waanders, G., and Kuehne, P.A., 2011, Early results of a study of Middle Jurassic strata in the Sevier fold and thrust belt, Utah, in Sprinkel, D.A., Yonkee, W.A., and Chidsey, T.C., Jr., editors, Sevier thrust belt-northern and central Utah and adjacent areas: Utah Geological Association Publication 40, p. 151-172.

Wang, Y., Chan, M.A., and Merino, E., 2015, Self-organized iron-oxide cementation geometry as an indicator of paleo-flows: Scientific Reports, v. 5, p. 10792.

Wheatley, D.F., and Chan, M.A., 2018, Clastic pipes and soft-sediment deformation of the Jurassic Carmel Formation, southern Utah, U.S.A._-implications for pipe deformation mechanisms and host-rock controls: Journal of Sedimentary Research, v. 88, p. 1076-1095, doi:10.2110/jsr.2018.45

Wheatley, D.F., Chan, M.A., and Sprinkel, D.A., 2016, Clastic pipe characteristics and distributions throughout the Colorado Plateau-implications for paleoenvironment and paleoseismic controls: Sedimentary Geology, v. 344, p. 20-33, doi:10.1016/j. sedgeo.2016.03.027. 